\title{
Spatiotemporal dynamics of soil rotifers in a South-Bohemian beech forest
}

\author{
Miloslav Devetter(1) \\ (1)Academy of Science of the Czech Republic, Biology Centre, Institute of Soil Biology, Na sádkách 7, 37005 České Budějovice, Czech \\ Republic. E-mail: devetter@upb.cas.cz
}

\begin{abstract}
The objective of this work was to determine seasonal variation and vertical distribution of the soil rotifer assemblage in a climax beech forest in South Bohemia. During 2005, soil rotifer was investigated to the species level. Soil samples of $10 \mathrm{~cm}^{2}$ and $10 \mathrm{~cm}$ in depth were divided into five layers, which were processed separately. Thirty one rotifer species were identified during the investigation. Dominant species significantly changed throughout the seasons. The most abundant species were Encentrum arvicola and Wierzejskiella vagneri among the monogononts, and Adineta steineri, Ceratotrocha cornigera, Habrotrocha filum, Habrotrocha ligula, Macrotrachela plicata, Mniobia tentans, Mniobia incrassata and Mniobia granulosa among the bdelloids. Mean Shannon diversity index varied from 1.99 to 2.63 . Total rotifer abundance varied from $212 \pm 63$ to $513 \pm 12710^{3}$ individuals $\mathrm{m}^{-2}$ along the year, with the highest numbers found in May, and the lowest in July. The great part of the community was concentrated in the upper (fresh litter) and second (partially decomposed litter) layers and significantly decreased in the soil vertical profile on all sampling dates. The highest rotifer density of 43 individuals $\mathrm{g}^{-1}$ was found in the upper layer in May.
\end{abstract}

Index terms: Bdelloidea, Monogonota, Rotifera, seasonal dynamics, vertical distribution.

\section{Dinâmica espaço-temporal de rotíferos edáficos em uma floresta de faias no sul da Boêmia}

\begin{abstract}
Resumo - O objetivo deste trabalho foi determinar a variação sazonal e a distribuição vertical de comunidades de rotíferos edáficos em uma floresta de faias em clímax, no Sul da Boêmia. Durante 2005, as comunidades de rotíferos edáficos foram estudadas até o nível da espécie. Amostras de $10 \mathrm{~cm}^{2}$ de área com $10 \mathrm{~cm}$ de profundidade foram divididas em cinco camadas, que foram processadas separadamente. Trinta e uma espécies de rotíferos foram identificadas durante a investigação. Todas as espécies dominantes tiveram variações significativas durante as estações climáticas. As espécies mais abundantes foram Encentrum arvicola e Wierzejskiella vagneri entre os monogonontes e Adineta steineri, Ceratotrocha cornigera, Habrotrocha filum, Habrotrocha ligula, Macrotrachela plicata, Mniobia tentans, Mniobia incrassata e Mniobia granulosa entre os bdelloides. O índice médio de diversidade de Shannon variou entre 1,99 e 2,63. A abundância total de rotíferos variou entre $212 \pm 63$ e $513 \pm 12710^{3}$ indivíduos por $\mathrm{m}^{2}$ ao ano, com os maiores números encontrados em maio e os menores em julho. A maior parte da comunidade estava concentrada na camada superior (liteira fresca) e na segunda camada (liteira parcialmente decomposta) e diminuiu significativamente no perfil vertical do solo em todas as datas de coleta. A maior densidade de rotíferos, de 43 indivíduos $\mathrm{g}^{-1}$, foi encontrada na camada superior em maio.
\end{abstract}

Termos para indexação: Bdelloidea, Monogonota, Rotifera, dinâmica sazonal, distribuição vertical.

\section{Introduction}

Soil and litter-dwelling rotifer communities are important representants of part of the terrestrial soil habitats. Although rotifers form a significant fraction of interstitial communities in soils (Pourriot, 1979), the group has not received any attention in recent times. Descriptive studies prevail within the rather limited literature. Classical papers (Donner, 1951, 1952, 1965, 1970, 1972, 1980; Schulte, 1954; Varga, 1959, 1960,
1962) deal primarily with species composition and explain very little about abundances and ecological relations (Varga, 1961). Anderson et al. (1984) suggest that rotifers, as an important ecological component of soil, may play a significant role in the cycling of nutrients in the soil.

The understanding of the ecology of soil rotifers is extremely incomplete, but it is presumed that a major role of these organisms is to be predators of bacteria.

Pesq. agropec. bras., Brasília, v.44, n.8, p.1027-1032, ago. 2009 
They are microphagous, and also feed on fungi and microscopic algae (Schmid-Araya, 1998). Monogonts (Monogononta) comprise around $10 \%$ of rotifer specimens in the order level. They capture the food by scraping. Bdelloids (Bdelloidea) are a dominant group among soil rotifers inhabiting mostly the soil top layers (Pourriot, 1979). However, bdelloids are very difficult to identify, even at the genus level, because generally only living animals can be identified (Donner, 1965; Fontaneto \& Melone, 2003). Seasonal changes of soil rotifer species composition have not been studied yet, nor have their vertical distribution in the soil profile.

The objectives of this work were to test the seasonal changes of rotifer community composition as well as the abundance of individual species, and to assess the pattern of their vertical distribution in the soil profile.

\section{Materials and Methods}

The study was carried out in a climax beech forest in the protected area on the peak of Klet' Mountain (48 52'19.566"N, 14¹6'27.24"E), South Bohemia, Czech Republic. The elevation of the site is of $1,026 \mathrm{~m}$ above see level. Precipitation in the area averages $700-900 \mathrm{~mm}$ per year and the mean annual air temperature is $5-7^{\circ} \mathrm{C}$. The rotifers were studied in a natural forest composed mainly of beech trees (Fagus sylvatica) mixed with spruce (Picea abies) and maple (Acer pseudoplatanus).

From February to December 2005, five soil samples were taken using a cylindrical corer with a $10-\mathrm{cm}^{2}$ area down to a depth of $10 \mathrm{~cm}$. Each core was divided into five layers according to its character: litter, fermentation layer, fermentation layer with roots, humus layer, mineral layer. The thickness of each layer was of about $2 \mathrm{~cm}$. Ten random core replicates were combined to the mixed sample separately for each layer. The samples were transported to the laboratory and stored in a refrigerator. Five subsamples of each composite sample were processed by rotifer isolation. The water content of the samples varied between 30 and $80 \%$ depending on the season and soil profile. Rotifers were extracted from the soil using a modified Baermann funnel method (Overgaard-Nielsen, 1949) with distilled water, applying a combined light and temperature gradient. Living specimens were collected from the extraction water and counted using a counting chamber. The Shannon \& Weaver (1949) species diversity index (ln) was calculated. Rotifers were identified using Donner (1965) and Bartoš (1959). ANOVA was used for population comparison through the season.

\section{Results and Discussion}

A total of 31 species of rotifers ( 9 monogononts and 22 bdelloids) were determined along the whole studied period (Table 1). In spite of the high heterogeneity in abundance of many species among the subsamples, the populations of a great number of species significantly changed during the year. Two species, Macrotrachela papillosa and M. quadricornifera, although relatively easy to determine, were stably present regardless of the season.

The most common and abundant species were Encentrum arvicola, Wierzejskiella vagneri, Adineta vaga, A. steineri, Habrotrocha filum, H. ligula, Macrotrachela nana, M. plicata, Mniobia granulosa, $M$. incrassata and $M$. tentans. The number of species per site varied from 14 in September to 23 in May (Table 1), which corresponded to a Shannon diversity index from 1.99 to 2.63 (Figure 1). The Shannon index in the vertical profile was higher in the litter layer (February, July, December) or in the first fermentation layer (May, September), and always decreased in the deeper strata. The difference between upper and lower strata increased from winter to autumn.

Rotifer abundance (Figure 2) varied significantly from $212 \pm 62 \quad 10^{3}$ individuals $\mathrm{m}^{-2}$ in July to $513 \pm 12710^{3}$ individuals $\mathrm{m}^{-2}$ in May $(\mathrm{p}<0.001)$. The population was dominated by $M$. plicata and $H$. ligula in February, M. plicata in May, H. filum in July, H. filum and M. tentans in September and Ceratotrocha cornigera, Encentrum arvicola and M. plicata in December (Figure 3).

The seasonal changes in Encentrum species appear to be remarkable. The highest densities were reached in December after leaf fall. They decreased in winter and remained very low through the warm season. Similarly, Adineta steineri showed the highest numbers in February, and A. vaga and $W$. vagneri peaked in February and May respectively. Encentrum, Adineta and Wierzejskiella are genera that move with high speed in soils. On the other hand, C. cornigera was present from July to December, with no specimens found in February and May. Habrotrocha filum was 
one of the most important species present throughout the study, although its highest density occurred from July to September, when many species were at their minimum. Habrotrocha ligula reached its maximum in February, as did M. plicata and M. granulosa, which prefers the cold part of the season (Table 1).

Rotifer abundance in each layer varied considerably during the year. The majority of soil rotifers was present in the three upper layers (about $6 \mathrm{~cm}$ down from the surface), the litter and the two fermentation layers, at all sampling dates (Figure 4). Rotifer abundance decreased with increasing depth, while in February the highest numbers were found in the second layer, at a depth of 2-4 cm below the surface. The mean density of rotifers in the upper litter layer varied from 7 to $43 \mathrm{~g}^{-1}$, with its maximum in May. Total rotifer densities significantly decreased along the vertical profile on all sampling dates $(\mathrm{p}<0.001)$. Densities significantly differed among all adjacent layers in February, among the three upper layers in May, and among the upper two layers in the other cases $(\mathrm{p}<0.05)$. It appears that the vertical profile of temperature in the soil may influence the presence of rotifers. On the sampling dates, when the temperature was markedly higher at the surface than at the deeper strata, the difference among rotifer densities was remarkable in the upper and lower layers (May, July). On the other hand, when the temperature profile was reversed, the difference between the rotifer surface and the deeper densities was less evident. Soil moisture, measured as the proportion of wet mass, did not change significantly throughout the season, except in the upper litter layer. This layer's substrate was composed of 55 to $81 \%$ of moisture content, which was maximal in December and minimal in July.

Table 1. List of rotifer species and their densities (mean \pm SD $10^{3}$ individuals $\mathrm{m}^{-2}$ ) according to seasonal changes.

\begin{tabular}{|c|c|c|c|c|c|c|}
\hline \multirow[t]{2}{*}{ Species } & \multicolumn{5}{|c|}{ Sampling date } & \multirow[b]{2}{*}{$\mathrm{F}$} \\
\hline & $25 \mathrm{Feb}$. & 19 May & 27 July & 29 Sept. & 16 Dec. & \\
\hline \multicolumn{7}{|l|}{ Monogononta } \\
\hline Bryceella stylata (Milne, 1886) & & & & & $2 \pm 3$ & $3.1 *$ \\
\hline Cephalodella sp. & $1 \pm 1$ & $2 \pm 2$ & & & $2 \pm 1$ & $5.7 * *$ \\
\hline Colurella cf. colurus (Ehrenberg, 1830) & & & $<1$ & $<1$ & & 0.8 \\
\hline Colurella uncinata (Müller, 1773) & $<1$ & $<1$ & $<1$ & & & 1.0 \\
\hline Colurella hindenburgi Steinecke, 1917 & & & & & $1 \pm 1$ & $13.7 * * *$ \\
\hline Encentrum arvicola Wulfert, 1936 & $10 \pm 6$ & & $<1$ & $1 \pm 2$ & $22 \pm 13$ & $14.0 * * *$ \\
\hline Encentrum martes Wulfert, 1939 & & & & & $5 \pm 5$ & $5.4 * *$ \\
\hline Encentrum sp. & $<1$ & $1 \pm 1$ & & & & 1.0 \\
\hline Wierzejskiella vagneri Koniar, 1955 & $14 \pm 11$ & $15 \pm 10$ & $9 \pm 9$ & $1 \pm 2$ & $2 \pm 1$ & $3.6^{*}$ \\
\hline \multicolumn{7}{|l|}{ Bdelloidea } \\
\hline Adineta steineri Bartoš, 1951 & $14 \pm 9$ & $4 \pm 2$ & $1 \pm 1$ & & $2 \pm 1$ & $13.1 * * *$ \\
\hline Adineta vaga (Davis, 1873) & $5 \pm 5$ & $8 \pm 4$ & $1 \pm 1$ & $1 \pm 0$ & $9 \pm 4$ & $6.4^{* *}$ \\
\hline Ceratotrocha cornigera (Bryce, 1893) & & & $8 \pm 4$ & $5 \pm 3$ & $43 \pm 26$ & $47.4 * * *$ \\
\hline Habrotrocha aspera (Bryce, 1892) & & & $11 \pm 6$ & & & $26.3 * * *$ \\
\hline Habrotrocha elegans (Milne, 1886) & $1 \pm 0$ & $3 \pm 2$ & & & $<1$ & $8.0 * * *$ \\
\hline Habrotrocha filum Donner, 1949 & $9 \pm 6$ & $6 \pm 3$ & $22 \pm 9$ & $21 \pm 7$ & $5 \pm 3$ & $28.4 * * *$ \\
\hline Habrotrocha lata (Bryce, 1892) & & $2 \pm 2$ & & & & $8.0 * * *$ \\
\hline Habrotrocha leitgebii (Zelinka, 1886) & & $3 \pm 3$ & & & & $7.6 * * *$ \\
\hline Habrotrocha ligula Bryce, 1913 & $28 \pm 13$ & $5 \pm 2$ & $4 \pm 4$ & $1 \pm 1$ & $2 \pm 1$ & $24.2 * * *$ \\
\hline Habrotrocha rosa Donner, 1949 & $1 \pm 2$ & & & & & $3.0^{*}$ \\
\hline Habrotrocha $\mathrm{sp}$ & & $3 \pm 2$ & & & $<1$ & $23.5 * * *$ \\
\hline Macrotrachela nana (Bryce, 1912) & & $14 \pm 8$ & $2 \pm 3$ & $7 \pm 2$ & $7 \pm 5$ & $29.9 * * *$ \\
\hline Macrotrachela papillosa Thompson, 1892 & $<1$ & $2 \pm 1$ & $1 \pm 1$ & $2 \pm 2$ & $3 \pm 2$ & 1.8 \\
\hline Macrotrachela plicata (Bryce, 1892) & $28 \pm 15$ & $21 \pm 8$ & $12 \pm 10$ & $15 \pm 5$ & $22 \pm 11$ & $6.3 * *$ \\
\hline Macrotrachela quadricornifera Milne, 1886 & $2 \pm 2$ & $3 \pm 2$ & $2 \pm 2$ & $2 \pm 1$ & $<1$ & 1.9 \\
\hline Macrotrachela sp. & $2 \pm 3$ & $1 \pm 1$ & & & & 1.5 \\
\hline Mniobia granulosa Bartoš, 1940 & $13 \pm 9$ & $10 \pm 7$ & $5 \pm 2$ & $7 \pm 6$ & $5 \pm 3$ & $3.3^{*}$ \\
\hline Mniobia incrassata (Murray, 1905) & $2 \pm 2$ & $11 \pm 6$ & $2 \pm 2$ & $10 \pm 6$ & $3 \pm 3$ & $22.7 * * *$ \\
\hline Mniobia russeola (Zelinka, 1891) & & $<1$ & & & & 1.0 \\
\hline Mniobia tentans Donner, 1949 & $20 \pm 10$ & $16 \pm 10$ & & $37 \pm 20$ & $12 \pm 4$ & $17.7 * * *$ \\
\hline Mniobia sp. & $13 \pm 5$ & & $1 \pm 1$ & & & $56.9 * * *$ \\
\hline Rotaria sordida (Western, 1893) & & $<1$ & & & & 1.0 \\
\hline
\end{tabular}

$*$, ** and ***Significant at 5,1 and $0.1 \%$ probability by the $\mathrm{F}$ test. 
Although the total rotifer densities were commonly the highest in the upper litter layer, only a few species followed this trend in general. The Encentrum and Adineta genera and the M. plicata species highly preferred the litter and were found at much lower densities in other strata. Habrotrocha filum was usually at its highest densities in the litter, but was relatively abundant in the fermentation and the humus layers too. Mniobia incrassata was always most abundant in the fermentation layers. Wierzejskiella vagneri preferred the deeper lower fermentation and humus strata for all sampling dates. This was also seen for M. tentans.

This is the first study documenting large seasonal changes in species composition, as well as the

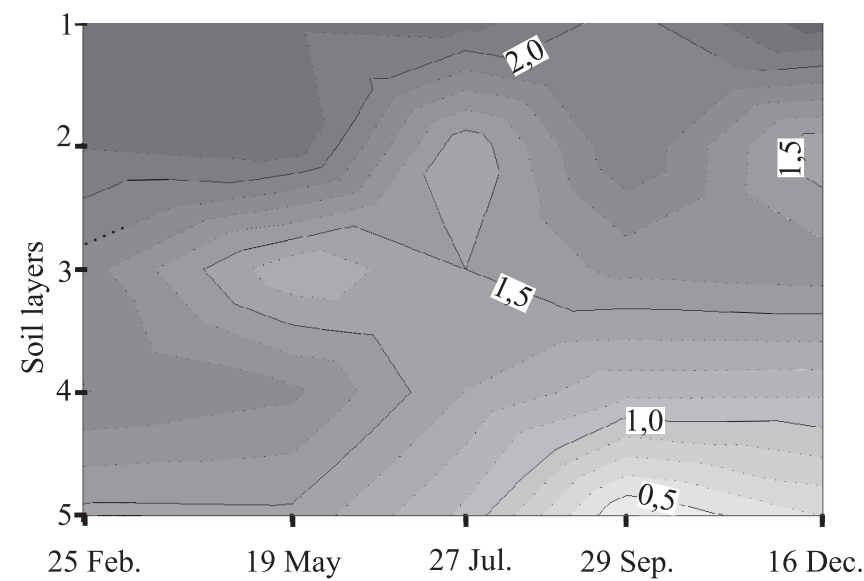

Figure 1. Spatiotemporal changes in the Shannon diversity index on soil vertical profile (up to $10 \mathrm{~cm}$ ) over the seasons.

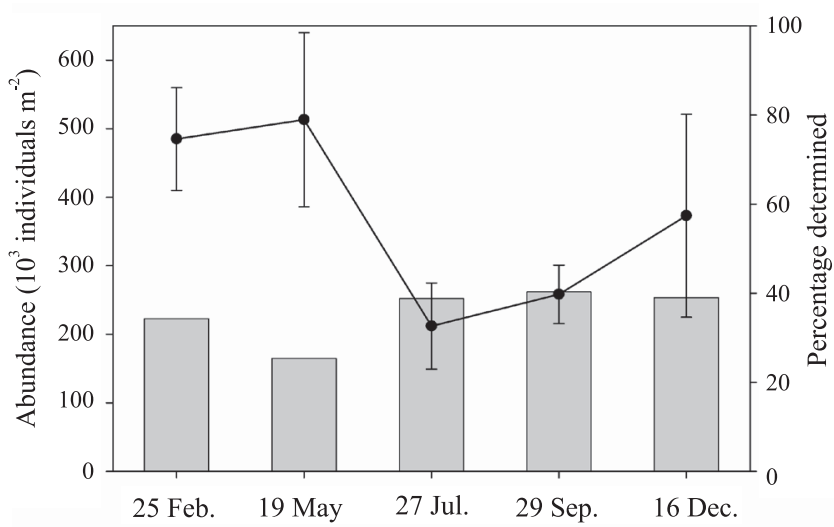

Figure 2. Seasonal changes in total rotifer abundance $(\bullet$, mean \pm SD $)$ and percentage of animal community directly determined through analysis (bars). abundance of species in rotifer communities in the soil. The results suggest that species react to changing environmental conditions in terms of their dynamics and vertical distribution. The fact that practically all important species (except M. papillosa) show significant changes in abundance, in spite of high variability among replicates, indicates that seasonal trends are highly important.

The rotifer community is relatively diverse in beech forests. The number of species found in this habitat is comparable to that of Donner $(1970,1972)$, and significantly higher than the one in the samples from the Kokořínsko PLA (Devetter, 2007b). The total species diversity as well as the total rotifer densities of

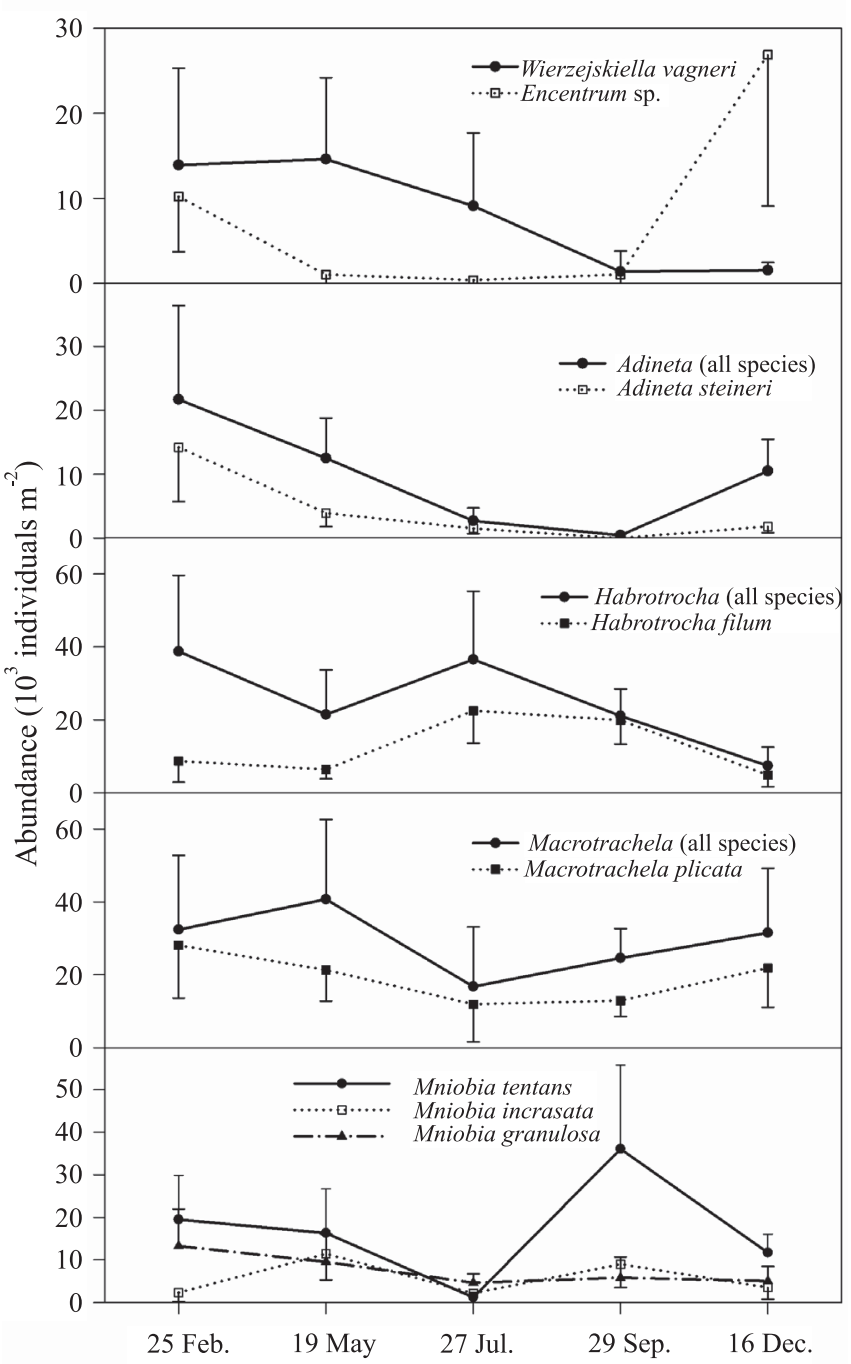

Figure 3. Abundance seasonal changes (2005) in main rotifer species (mean $\pm \mathrm{SD}$ ). 


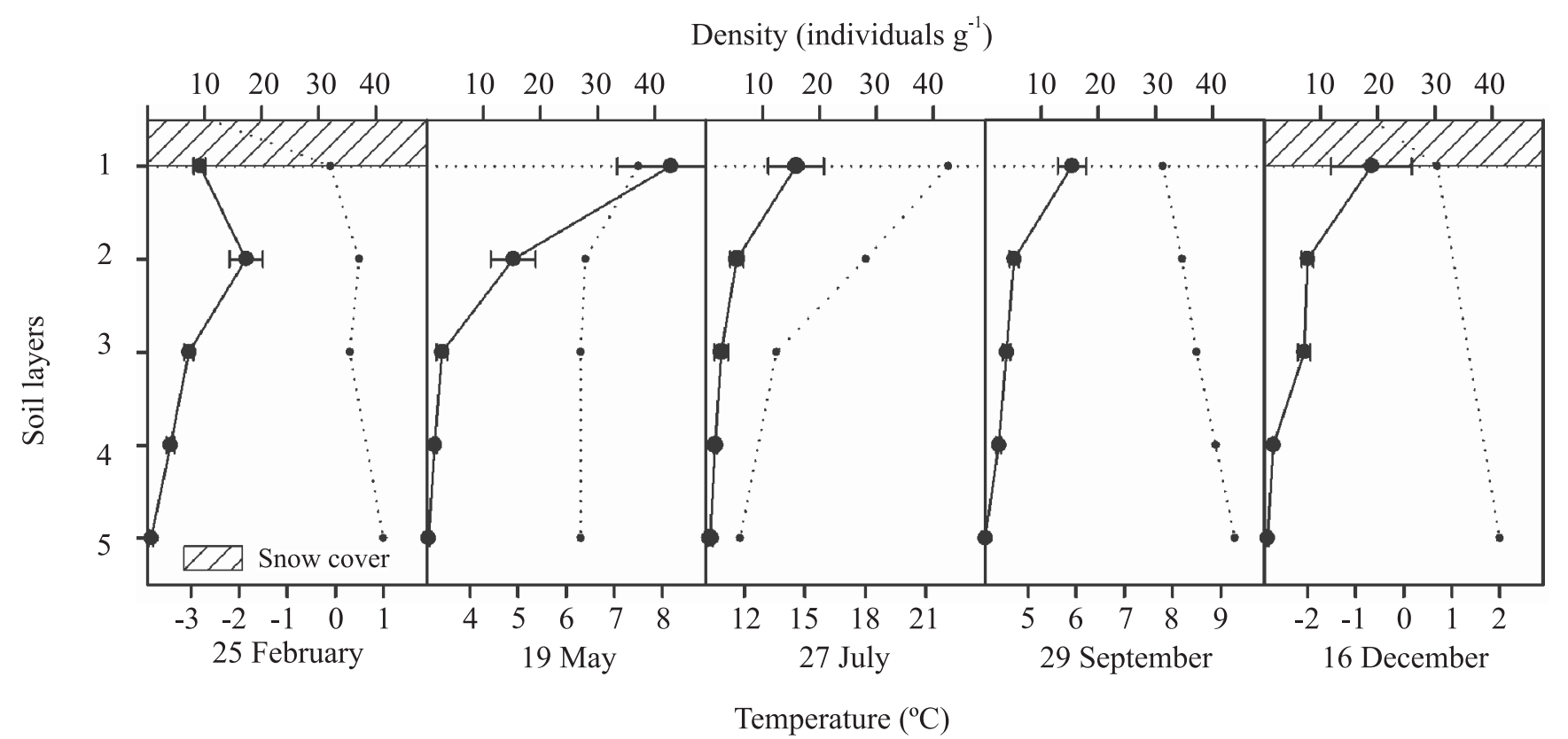

Figure 4. Seasonal vertical distribution (up to $10 \mathrm{~cm}$ ) of rotifer density (solid line) according to soil temperature (dotted line).

soil rotifers from brown coal post-mining dumps are also lower than in this study (Devetter, 2007a).

There are few quantitative accounts of total soil rotifer numbers published (Schulte, 1954; Pourriot, 1979; Sohlenius, 1979, 1982; Anderson et al., 1984; Háněl, 2000). Estimates by these authors range from 300 to $2,10010^{3}$ individuals $\mathrm{m}^{-2}$. The results of this study fall within this range. However, rotifers were always referred to as a group in these earlier studies, none of which identified rotifers systematically (Schmid-Araya, 1998). Past results have shown a high heterogeneity and variability between subsamples, which is typical for soil (Háněl, 1995).

The vertical distribution pattern of soil rotifers with upper layer maxima, as described in this study, was also mentioned by Pourriot (1979), but without any data. Therefore, such results are also important for understanding the role of rotifers in soils. However, not every species follows the general trend, and some of them form strong maxima in deeper strata of the soil profile.

Macrotrachela plicata appeared to be the most abundant rotifer species. It was present in all seasons and is commonly referred to by Donner (1970) and Pourriot (1979). Encentrum arvicola and E. martes, which were commonly found in this study, are not reported in other studies. In addition, E. arvicola was recently found by the author in different localities (Devetter, 2007a). On the other hand, E. mustela and E. rapax are often found in soil habitats (Varga, 1959, 1962; Donner, 1970, 1972). Encentrum species were most important after the leave fall, in winter. Although A. vaga, A. steineri, H. rosa, M. nana, M. papillosa, $M$. quadricornifera and $R$. sordida are reported in most of the relevant papers (Varga, 1959, 1960, 1962; Donner, 1970, 1972), C. cornigera, H. aspera, H. filum, M. plicata, M. russeola and M. tentans were found only by Donner and H. elegans, H. leitgebii, H. ligula and $M$. incrassata are mentioned only by Varga. Similarly, Varga $(1959,1962)$ found B. stylata in soil samples, but this species is not mentioned in Donner's papers. Wierzejskiella vagneri was not reported in any of the papers mentioned above, which possibly means that this species is not very common.

\section{Conclusions}

1. Soil rotifer species react to changing environmental conditions, and seasonal trends are highly important to their dynamics and vertical distribution regarding abundance and diversity.

2. Rotifers in soils compose a well-developed, autochthonous community, which consists of species typical for such an environment. 


\section{Acknowledgements}

To the Czech Science Foundation, for the research grants; to Keith Edwards, for reviewing the English text. This study was supported by research grants GAČR206/06/P405 and AV02 60660521.

\section{References}

ANDERSON, R.V.; INGHAM, R.E.; TROFYMOW, J.A.; COLEMAN, D.C. Soil mesofaunal distribution in relation to habitat types in shortgrass prairie. Pedobiologia, v.26, p.257-261, 1984.

BARTOŠ, E. Viŕníci-Rotatoria. Prague: Fauna ČSR, 1959.

DEVETTER, M. Primary succession of soil rotifer communities on brown coal post-mining area. In: TAJOVSKÝ, K.; SCHLAGHAMERSKÝ J.; PIŽL, V. (Ed.). Contributions to Soil Zoology in Central Europe II. České Budějovice: ISB BC AS CR, 2007a. p.25-27.

DEVETTER, M. Soil Rotifers (Rotifera) of the Kokořínsko Protected Landscape Area. Biologia, v.62, p.222-224, 2007b.

DONNER, J. Bodenrotatorien im Winter. Mikrokosmos, v.42, p.29-33, 1952.

DONNER, J. Erste Übersicht über die Rotatorienfauna einiger Humusboden. Österreichische Zoologische Zeitschrift, v.3, p.175-240, 1951.

DONNER, J. Ordnung Bdelloidea (Rotatoria, Rädertiere). Berlin: Akademie-Verlag, 1965. 297p.

DONNER, J. Rotatorien aus einigen Böden des östlichen Österreich. Revue d'Ecologie et de Biologie du Sol, v.9, p.671-682, 1972.

DONNER, J. Rotatorien aus einigen Böden und Moosen Spaniens und seiner Inseln. Revue d'Ecologie et de Biologie du Sol, v.7, p.501-532, 1970.

DONNER, J. Some new researches about bdelloid rotifers, especially those in soils. Revue d'Ecologie et de Biologie du Sol, v.17, p.125-143, 1980.

FONTANETO,D.; MELONE, G. Bdelloid rotifers from lakes above $1700 \mathrm{~m}$ in Western Italian Alps, with taxonomic notes on Dissotrocha macrostyla. International Review of Hydrobiology, v.88, p.594-601, 2003.
HÁNĚL, L. Seasonal changes of soil nematodes, other soil microfauna and fungus fruiting bodies in a spruce forest near České Budějovice, Czech Republic. Biologia, v.55, p.435-443, 2000.

HÁNĚL, L. Secondary successional stages of soil nematodes in cambisols of South Bohemia. Nematologica, v.41, p.197-218, 1995.

OVERGAARD-NIELSEN, C. An apparatus for quantitative extraction of nematodes and rotifers from soil and moss. Natura Jutlandica, v.1, p.271-277, 1949.

POURRIOT, R. Rotiferes du sol. Revue d'Ecologie et de Biologie du Sol, v.16, p.279-312, 1979.

SHANNON, C.E.; WEAVER, W. The mathematical theory of comunication. Urbana: Universitu of Illinois Press, 1949.

SCHMID-ARAYA, J.M. Rotifers in interstitial sediments. Hydrobiologia, v.388, p.231-240, 1998.

SCHULTE, H. Beiträge zur Ökologie und Systematik der Bodenrotatorien. Zoologische Jahrbücher, v.82, p.497-652, 1954.

SOHLENIUS, B. A carbon budget for nematodes, rotifers and tardigrades in a Swedish coniferous forest soil. Holarctic Ecology, v.2, p.30-40, 1979.

SOHLENIUS, B. Short-term influence of clear-cutting on abundance of soil microfauna (Nematoda, Rotatoria and Tardigrada) in Swedish pine forest soil. Journal of Applied Ecology, v.19, p.349-359, 1982.

VARGA, L. Beiträge zur Kenntnis der streubewohnenden Mikrofauna des Aszóföer Waldes sowie zur Anabiose dieser Mikrofauna. Annals of Biology Tihany, v.28, p.203-209, 1961.

VARGA, L. Über die Mikrofauna der Waldstreu einiger auf Szikboden angelegter Waldtypen. Acta Zoologica Hungaricae, v.6, p.211-225, 1960.

VARGA, L. Über die Mikrofauna der Waldstreu von zwei Waldtypen des Durmitor-Gebirges (Jugoslawien). Bulletin du Museum d'Histoire Naturelle De Belgrade, Section B, v.18, p.145-158, 1962.

VARGA, L. Untersuchungen über die Mikrofauna der Waldstreu einiger Waldtypen im Bukkgebirge (Ungarn). Acta Zoologica Hungaricae, v.4, p.443-478, 1959. 